\title{
Design and Development of Affective 4-Dimensional Mobile Mathematics for Low Vision Alpha Generation
}

\author{
Nurulnadwan Aziz ${ }^{1}$, Siti Zulaiha Ahmad ${ }^{2}$, \\ Wan Rahzihan Zulnasyreeq Wan A Rahman ${ }^{3}$, Sariya Binsaleh ${ }^{4}$ \\ ${ }^{1}$ Universiti Teknologi MARA Cawangan Terengganu, 23000 Dungun, Terengganu, Malaysia \\ ${ }^{2}$ Universiti Teknologi MARA Cawangan Perlis,, 02600 Arau, Perlis, Malaysia \\ ${ }^{3}$ RPA Revolution Enterprise, P-2-6, Pangsapuri Sinar, Bandar Salak Perdana, 43900, Sepang, \\ Selangor, Malaysia \\ ${ }^{4}$ Prince of Songkla University, Thailand
}

\begin{abstract}
In this digital era, low vision children should learn Mathematics by using similar learning content provided for mainstream students. Teachers need to express their feeling, thought, emotions, and actions to ensure the low vision learners can grasp the mathematics content. However, it is too tough for low vision children to adapt to the common learning content which is in contrast with their needs. Consequently, this study aims to develop Affective 4Dimensional Mobile Mathematics for Low Vision Alpha Generation. This study adapted the 3-Phases Development Model. Accordingly, the findings of this study are the design and development of the abovementioned application.
\end{abstract}

Keywords - Mobile Human-Computer Interaction, Affective Design, Assistive Technology, User-centred Design Approach, User Experience, Low Vision.

DOI: $10.18421 /$ TEM104-46

https://doi.org/10.18421/TEM104-46

Corresponding author: Nurulnadwan Aziz, Universiti Teknologi MARA Cawangan Terengganu, 23000 Dungun, Terengganu, Malaysia.

Email: nurulnadwan@uitm.edu.my

Received: 23 October 2021.

Revised: 17 November 2021.

Accepted: 23 November 2021.

Published: 26 November 2021.

(c) BY-NC-ND (C) 2021 Nurulnadwan Aziz et al; published by UIKTEN. This work is licensed under the Creative Commons Attribution-NonCommercial-NoDerivs 4.0 License.

The article is published with Open Access at www.temjournal.com

\section{Introduction}

In this digital era of education 5.0, producing a knowledgeable civil society that covers the aspects of creation, dissemination, and utilization of knowledge and information are the important factors to accelerate the advancement of the country. This includes Persons with Disabilities (PWDs) where they are also a part of the resource for the country that can contribute to the successful production in many sectors. Therefore, assisting their living with Assistive Technology (AT) is a necessity to ensure they are included in the agenda of digital inclusion and knowledgeable civil society. This agenda is under the responsibility of researchers and industrial practitioners as their social contribution to the country.

Due to that, a lot of ATs have been designed and developed for PWDs in the form of hardware and software which include low-tech, medium-tech, and high-tech. They are designed based on the disabilities themselves. Generally, the government of the countries (i.e., Ministry of Education) equips the ATs in special education schools and integrated schools [1]. Some of the selected schools are usually Special Education Primary School equipped with computer lab facilities for example screen readers, screen magnification, and high-tech speakers. This is to ensure the students with disabilities acquire the similar accessibility of knowledge as mainstream students. Currently, typical ATs which are Closed Circuit Television (CCTV) and magnifying glass were utilized by the low vision children in accessing the concept of Mathematical operations [2]. Initial interview with experts [1], [2], [3] reveals that utilizing both of these ATs requires the help of human readers (i.e., a teacher) all the time at their side which is impractical to train the low vision children to learn independently. Typical magnifying 
glass and CCTV have no audio provided as the low vision children depend $100 \%$ on audio to recognize the content. Besides, Braille also is convenient AT used in expressing the Mathematics content to visually impaired students including low vision children. Unfortunately, not all Mathematics content is accessible in Braille as producing the Mathematics code and scientific formulas including the expressions and objects were complex and complicated. Moreover, reading Braille Mathematics code is quite tedious and ambiguous due to the additional meaning of the cells even to the users who are Braille literate [4]. Other ATs for low vision children that are available in the market are talking books prepared particularly for children [5]. However, these types of books are less provided for Mathematics and scientific operations.

According to the experts [1], [2], [3], another alternative to typical AT software that has been used widely in special education schools is the text-tospeech (TTS) engine. TTS is software that converts digital text into synthetic speech. Presently, TTS has been designed according to individual needs (i.e., speech disability, low vision children). This means that screen readers and TTS technologies contribute to developing reading skills among the low vision children. However, most of the TTS engines are able to read only plain text which means it is unable to assist the low vision children to read the scientific Mathematics formulas, symbols, and operations.

Moreover, high skill is required in accessing the Math information that is mostly available in the form of graphics as that information has to be utilized in solving Mathematical problems. Prior research indicates that low vision children face difficulties locating information in Math graphics, particularly those that involve expressions and objects [6]. Based on the series of interviews that have been carried out with experts [1], [2], [3]; understanding the Mathematical concept is the most critical subject for the low vision children in schools. As the low vision children face challenges in identifying the Mathematical expressions and objects due to their limitation in accessing the visual information, teachers need to enhance their effort as much as they can compared to mainstream students. The teacher's effort also requires a lot of energy and creativity to express the content. Limitations in identifying the expressions and objects are not the barrier because the low vision children have the similar cognitive ability as mainstream students [2], [7]. In normal practice, teachers need to express their emotions twice or threefold to ensure the low vision children are able to understand the concept of Mathematical operations delivered to them even if it is the basic concept. As reported by [3], usually a lot of tangible materials such as colorful papers, fruits, and foods have been utilized to express the concept of Mathematical operations to low vision children. However, having these materials always is impractical because of the cost and the limited energy of the teachers [1], [2].

To strengthen the problem of the study, a series of initial interviews with experts from the Special Education School has been conducted. They are [1], [2], [3]. It is reported that in Malaysia, there are only five special schools specific for visual impairment including low vision children. They are located at Penang, Johor, Kuala Lumpur, Sabah, and Sarawak. All of these schools facilitate computer labs and Assistive Technology (AT) devices. However, there are also mainstream schools that integrate with visual impairment. Most of the low vision children in suburban areas of Malaysia study at the Integrated School of Visual Impairment. In school, the lowvision children access the Mathematics content through AT provided by the Ministry of Education Malaysia (MOE). There is a magnifying glass and Close Circuit Television (CCTV) [3]. Besides, once a week they have to learn together in the same class with the mainstream students [3]. This is an alternative method proposed by the school management which is included in the schedule in ensuring the low vision children have social contact with their mainstream peers [5]. However, accessing the concept of Mathematics operations by utilizing the provided AT requires their eyes to struggle too much compared to mainstream students. This problem leads them to get eyestrain which makes them feel annoying and frustrated in their learning activities [2]. Learning the concept of Mathematics operations through mainstream textbooks by utilizing magnifying glass and CCTV was problematic for the low vision as no audio was provided in both of these devices [2]. This psychologically affects their emotion and curiosity in understanding the basic concept of the Mathematics operations which then kills their learning interest [1], [7]. In addition, advanced magnifying glass or CCTV requires a lot of costs as this is the main problem for the parents to have it for their low vision child particularly in developing countries [4]. Again, there are no opportunities for the low vision children to learn or explore the concept of Mathematics operation on their own [1], [2], [3].

Thus, the development of Affective 4-Dimensional Mobile Mathematics for Low Vision children should conceptually address the main learning needs that are able to attract their attention during the learning activities. The intended prototype also should be able to offer a positive learning experience in supporting the low vision children interactively and attractively with enjoyment and encouragement concept [8]. In ensuring the students are able to absorb the learning 
content, they should actively involve the class activities [9]. Therefore, this could be supported by offering affective interactions experience specifically designed for low vision children. This is important to stimulate their learning interest by adapting comprehensive affective interaction concepts. Therefore, the next section discusses the thorough works of literature that cover the scope of this study.

\section{Related Works}

This section examines the related works that cover the scope of the study which are the current state of newly registered persons with disabilities, existing Mathematics applications for low vision children, addressing affective design concept and the main subject of the study which are the low vision alpha generation.

\subsection{The Current State of Newly Registered Persons with Disabilities (PWDs)}

Globally, the statistics show a rapid increment in the number of people with disabilities (PWDs). Currently, around $10 \%$ of the world's population or roughly 650 million people have some form of disability in which most of them live in developing countries [10]. Moreover, as estimated by the World Bank, $20 \%$ of the world's poorest people have some form of disability and tend to be regarded in their communities as the worst people [11]. In each of these years, it is estimated that over 1 million children with disabilities were born and unfortunately $90 \%$ of them do not attend school, particularly those who live in developing countries [10]. Also, many of them were abandoned by their parents due to the burden of long-term medical costs [11].

They are disabled differently including visual impairment, hearing impairment, speech impairment, learning disability, multiple disabilities, mental disability, and physical disability [12]. Among the various kinds of disabilities, visual impairment is one of the serious problems. As reported by [10] it is estimated that at least 2.2 billion people in the world have visual impairment including low vision. Furthermore, [11] also reveals that the number of visually impaired people in low-income countries and middle-income countries is four times higher than in high-income countries.

Meanwhile in Malaysia, as of December 2020, there were 578,591 of PWDs officially registered by the Malaysian Social Welfare Department [12]. From the total figure, there were 36,692 visually impaired people registered in 2017, and the number increased to 51,306 in December 2020 (Table 1).
Table 1. Cumulative number of registered persons with differently abled cases

\begin{tabular}{|c|c|c|c|c|}
\hline \multirow{2}{*}{$\begin{array}{c}\text { Type of } \\
\text { Disability }\end{array}$} & \multicolumn{4}{|c|}{ Year } \\
\cline { 2 - 5 } & 2017 & 2018 & 2019 & 2020 \\
\hline VI & $\mathbf{4 0 , 4 6 6}$ & $\mathbf{3 6 , 1 7 1}$ & $\mathbf{4 3 , 5 7 6}$ & $\mathbf{5 1 , 3 0 6}$ \\
\hline HI & 34,280 & 44,523 & 35,991 & 39,935 \\
\hline PI & 159,674 & 179,222 & 173,587 & 209,982 \\
\hline LD & 157,714 & 170,269 & 169,853 & 199,352 \\
\hline SP & 2,355 & 2,572 & 2,534 & 2,948 \\
\hline MP & 37,537 & 41,218 & 40,570 & 47,981 \\
\hline Others & 21,232 & 23,415 & 22,837 & 27,087 \\
\hline Total & $\mathbf{4 5 3 , 2 5 8}$ & $\mathbf{4 9 7 , 3 9 0}$ & $\mathbf{4 8 8 , 9 4 8}$ & $\mathbf{5 7 8 , 5 9 1}$ \\
\hline
\end{tabular}

\subsection{Existing Mathematics Application for Low Vision Children}

Table 2. List of existing Mathematics application for low vision children

\begin{tabular}{|c|c|}
\hline Proposed Application & Description \\
\hline $\begin{array}{l}\text { Web Application } \\
\text { Columnar Layout } \\
\text { Operations [13] }\end{array}$ & $\begin{array}{l}\text { Electronic supported method to } \\
\text { perform the columnar-layout } \\
\text { operation by students with } \\
\text { visual impairments. }\end{array}$ \\
\hline Eye-Math [14] & $\begin{array}{l}\text { Read aloud the Math content to } \\
\text { the users }\end{array}$ \\
\hline $\begin{array}{l}\text { Speech Synthesizers } \\
\text { Mathematics [4] }\end{array}$ & $\begin{array}{l}\text { Uses speech synthesizers to } \\
\text { read the Mathematical content. }\end{array}$ \\
\hline $\begin{array}{l}\text { Cognitive States } \\
\text { Mathematics [6] }\end{array}$ & $\begin{array}{l}\text { Train the visually impaired } \\
\text { children to solve Mathematical } \\
\text { tasks using their bodies. }\end{array}$ \\
\hline $\begin{array}{l}\text { iPad Apps for pre- } \\
\text { Algebra [15] }\end{array}$ & $\begin{array}{l}\text { Helping visually-impaired } \\
\text { students to study pre-algebra } \\
\text { and solve Mathematical words } \\
\text { problems. }\end{array}$ \\
\hline $\begin{array}{l}\text { Accessible Visual Math } \\
{[16]}\end{array}$ & $\begin{array}{l}\text { Focus on the most common } \\
\text { images used in Math content } \\
\text { such as tables, linens, graphs, } \\
\text { charts, and diagrams. }\end{array}$ \\
\hline $\begin{array}{l}\text { Local Cues to Indicate } \\
\text { Perspective in Tactile } \\
\text { Diagrams [17] }\end{array}$ & $\begin{array}{l}\text { Uses standard visual } \\
\text { perspective lines to represent } \\
\text { the object. }\end{array}$ \\
\hline $\begin{array}{l}\text { Multimodal Touch } \\
\text { Screen for Mathematics } \\
\text { Graphics [18] }\end{array}$ & $\begin{array}{l}\text { Uses vibrations and sounds to } \\
\text { present Mathematics Graphics } \\
\text { such as numbers, lines, tables, } \\
\text { pie chart, bar chart, line graph, } \\
\text { and maps. }\end{array}$ \\
\hline $\begin{array}{l}\text { Educational Board } \\
\text { Game [19] }\end{array}$ & $\begin{array}{l}\text { The proposed apps help the } \\
\text { teachers to teach Mathematical } \\
\text { Operations to visually } \\
\text { impaired children by utilizing } \\
\text { the computer as a central } \\
\text { processing element and } \\
\text { peripheral devices which are a } \\
\text { digital camera, speakers, and a } \\
\text { keypad. }\end{array}$ \\
\hline $\begin{array}{l}\text { A tangible user } \\
\text { interface-based } \\
\text { application [8] }\end{array}$ & $\begin{array}{l}\text { Low vision children are able to } \\
\text { determine the basic shape of } \\
\text { the object by touch, place them } \\
\text { on the surface, and receive } \\
\text { audio feedback in the context } \\
\text { of various learning activities. }\end{array}$ \\
\hline
\end{tabular}


Table 2 classified the existing Mathematics applications for low vision children. As explained in Table 1, all existing Mathematics applications highlight visually impaired students including low vision children as the target users (Table 2). All the applications provide accessibility of Mathematical content for low vision children. Each of them was presented in a different unique approach. There are elements of affective in some of the existing applications which allow the low vision children to gain emotion and actively get involved in the learning activities [14], [6]. Also, some applications train the low vision children to interact with the teachers and the provided content [19]. However, most of the applications required additional alternative devices and high-tech assistive technologies such as Braille alphabets, Job Access with Speech (JAWS), screen reading software, reading Braille textbook, digital camera, speakers, keypad, and speech synthesizers software. All this software and devices were challenging for low vision children to operate on their own. This means in using the existing Mathematics application they still need a facilitator to always facilitate them. Furthermore, the usage of high-tech assistive technologies was tough for developing countries to provide it to the users particularly for special schools.

Therefore, it ought to be noted that this is the research gap that should be the focal point of this study.

\subsection{Affective Design Concept}

In the context of this study, the design concept is subjected to suffice the needs of low vision children. According to [20] the design concept that suits users with disabilities is challenging as we have to adhere to their affective needs. Studies on affective design have proven that the value of outcome can be increased especially on the interface design [21], [22] and interaction behavior [23]. The concept of affective design is based on [20], [21], [23], [24] that address the inclusion of feelings, thought (perception), emotion and actions.

In addition, users including those with low vision usually gain either positive or negative experiences when involved in any activity that includes other parties, from which they may blend feelings, thoughts, emotions, and actions. User experience focuses on the consequence of users' perception in interacting with any product, system, service, or object [25]. Even though many studies argue the lack of user experience's exact definition, most of them agreed that it occurs based on the consequences of the behavior in the interaction process between users and the interactive model [26].

In conjunction with these two concepts, this study focuses on the feelings, thoughts, emotions, and actions on the consequences of the behavior of the interaction process within the low vision learning environment. Table 3 lists the affective components and elements that are to stimulate the low vision children's interest to have positive interactions during their learning activities.

\section{Table 3. Affective components and elements}

\begin{tabular}{|c|c|c|}
\hline 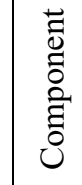 & Element & Description \\
\hline $\begin{array}{l}\stackrel{\infty}{\Xi} \\
\stackrel{0}{ \pm} \\
.1\end{array}$ & $\begin{array}{l}\text { - Pleasure } \\
\text { - Relax } \\
\text { - Excitement } \\
\text { - Enthusiasm } \\
\text { - Determination } \\
\text { - Attentiveness } \\
\text { - Inspired } \\
\text { - Interested }\end{array}$ & $\begin{array}{l}\text { Feelings are a conscious } \\
\text { experience, although not every } \\
\text { conscious experience, such as } \\
\text { seeing or believing, is a } \\
\text { feeling, It is a result of the } \\
\text { brain elevating the state of } \\
\text { emotion. [27] [the active } \\
\text { changes taking place in the } \\
\text { case of feelings are observed } \\
\text { as whole organism responses, } \\
\text { or reaction systems of the } \\
\text { acting person [28]. }\end{array}$ \\
\hline $\begin{array}{l}\vec{t} \\
\stackrel{0}{00} \\
\overrightarrow{0} \\
\stackrel{\Xi}{F}\end{array}$ & $\begin{array}{ll}\text { - } & \text { Perception } \\
\text { - } & \text { Cognitive }\end{array}$ & $\begin{array}{l}\text { Feeling and emotion that give } \\
\text { a great impact on thought. }\end{array}$ \\
\hline 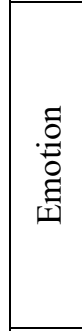 & $\begin{array}{ll}\text { - } & \text { Interest } \\
\text { - } & \text { Happiness } \\
\text { - Surprise } \\
\text { - Sadness } \\
\text { - } \text { Disgust Anger } \\
\text { - Fear } \\
\text { - } \text { Contempt } \\
\text { - Shame } \\
\end{array}$ & $\begin{array}{l}\text { Emotions generally refer to the } \\
\text { physiological response of the } \\
\text { brain and body to threats and } \\
\text { opportunities [29], [30]. }\end{array}$ \\
\hline & $\begin{array}{l}\text { - Interaction } \\
\text { - Navigation }\end{array}$ & $\begin{array}{l}\text { The actions of users while } \\
\text { interacting with the mobile } \\
\text { application express the users' } \\
\text { knowledge/thought, feeling, } \\
\text { and emotion. In the context of } \\
\text { mobile learning applications, } \\
\text { the user action can be in terms } \\
\text { of interaction and navigation } \\
\text { [31], [32]. } \\
\text { Examples of interactions are } \\
\text { keyboards input, the number of } \\
\text { clicks, text input, mouse } \\
\text { movement, scrolling, wrong } \\
\text { answer, correct answer, } \\
\text { knowledge mistake, the user } \\
\text { reads the theory, the user reads } \\
\text { the question of the test, } \\
\text { absence of action, and action } \\
\text { unrelated to the application } \\
\text { [31]. } \\
\text { Meanwhile, the examples of } \\
\text { action related to navigation are } \\
\text { link selection, extended } \\
\text { navigation in the application, } \\
\text { correct navigation, and wrong } \\
\text { navigation [32]. }\end{array}$ \\
\hline
\end{tabular}




\subsection{Low Vision Alpha Generation}

This study focuses on low vision. People with low vision mean their eyes have defects in vision functions that are unable to be corrected through spectacles, or contact lenses, or medical or surgical treatment [12]. This means they have a profound visual disability, but still retain some useful eyesight. Low vision results from two categories which are reduced visual acuity and restricted field of view [13]. In the context of this study, low vision refers to reduced visual acuity which means having a limited ability to discriminate the visual details. Meanwhile, alpha generation in this study refers to low vision children who were born entirely in the 21 st century. Most of them are children of Millennials and eager for technology.

\subsection{Summary of related works}

In accordance with the issue that has been discussed, it is confirmed that low vision children particularly the alpha generation need full support to assist them to understand the concept of Mathematical operations through the expressions and objects which could trigger their learning interest as they have the cognitive ability similar to mainstream students. Meanwhile, the affective design concept is important to be incorporated in the development of Affective 4-Dimensional Mobile Mathematics for Low Vision Alpha Generation to evoke the affective learning experience to low vision children.

\section{Methodology}

This study adapts a 3-phase development model [33] in conducting the research process. It consists of three (3) phases of the development process which are (i) pre-production (ii) production, and (iii) postproduction to accomplish the objective of this study. In addition to the development model, this study has conducted the User-Centered Design (UCD) approach in each phase to ensure the delivered application satisfies the user's needs. The following subsections elaborate on the activities and outcomes of each phase.

\subsection{The Development Processes}

Figure 1 illustrates the phases and the activities involved in the development process of Affective 4Dimensional Mobile for Low Vision Alpha Generation.

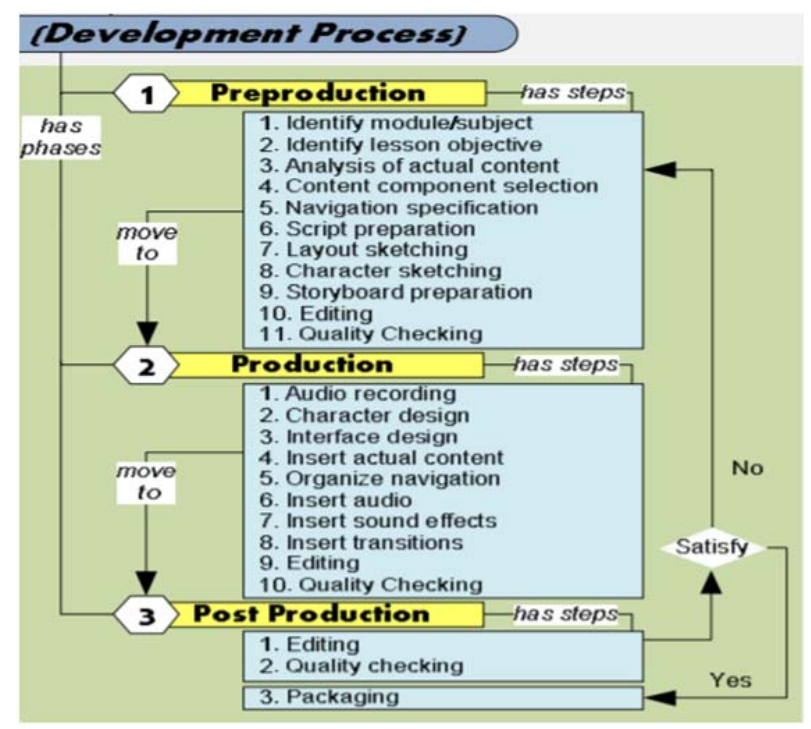

Figure 1. The 3-phases development model

The main objectives of the pre-development phase are to identify and prepare the learning resources as well as the initial plan in Affective 4-Dimensional Mobile Mathematics for Low Vision Alpha Generation. There are 11 steps involves in the preproduction phase which are (i) identify module/subject, (ii) identify lesson objective, (iii) analysis of actual content, (iv) content component selection, (v) navigation specification, (vi) script preparation, (vii) layout sketching, (viii) character sketching, (ix) storyboard preparation, (x) editing, and (xi) quality checking. Those activities have been conducted and delivered in the form of storyboards. The outcome of this phase has outlined the blueprints of the application as a low fidelity prototype. In order to ensure the quality of the design blueprints, it has been presented to the content experts from two Special Education Schools in Kedah and Pulau Pinang. Having completed phase one, the development process moves to phase two which is production. This phase aims to convert the low fidelity prototype into a high-fidelity prototype known as Affective Mobile Mathematics for Low Vision Alpha Generation. At this phase, (i) audio recording, (ii) character design, (iii) interface design, (iv) insert actual content, (v) organize navigation, (vi) insert audio, (vii) insert sound effects, (viii) insert transitions, (ix) editing, and (x) quality checking has been carried out. The outcome of this phase is an application that complies with the requirements of low vision users.

Meanwhile, (i) editing and (ii) quality checking has to be conducted at the post-production phase iteratively until the actual users, experts, and researchers are satisfied with the output. Packaging is the last step involved in the post-production phase after the Affective 4-Dimensional Mobile Mathematics for Low Vision Alpha Generation is completely produced. At the end of this stage, the product was ready to be published. 


\subsection{User-centered Design (UCD) Approach}

UCD approach means a comprehensive concentration at each phase of the prototype development is given to fulfill the requirements and limitations of end-users [34]. The decision on the development of the proposed prototype has been decided based on the findings and comments gathered from the end-users. In this study, low vision children, teachers, and industrial experts have been involved in justifying the design and development of Affective 4Dimensional Mobile Mathematics for Low Vision Alpha Generation. They were consulted as the proxy to acquire some additional suggestions and confirmations of the affective components and elements because of in-depth teaching experiences and that they are familiar with the low vision learning preferences.

\section{Findings}

The findings of this study are the design and development of Affective 4-Dimensional Mobile Mathematics for Low Vision Alpha Generation. This study utilizes Microsoft PowerPoint to design the storyboard, and Sound Forge for the recording and audio editing. Meanwhile, the latest version of Unity has been utilized to develop the mobile application. Considering vision impairment among the targeted users, this study suggests the suitable size of mobile device such as a 9" tablet (at least) to deliver the application. The next subsection discusses the application of affective dimensions that have been embedded into Affective 4-Dimensional Mobile Mathematics for Low Vision Alpha Generation.

\subsection{The Learning Content}

As suggested by the content experts, Fraction has been chosen as the learning content of Affective 4Dimensional Mobile Mathematics for Low Vision Alpha Generation because it is the basic topic of Mathematics subject at primary school level. However, it is the most complicated topic to be mastered by low vision children. There are 5 subtopics in the Fraction that are covered in this application which are (i) Proper Fraction, (ii) Equivalent Fraction, (iii) Simplifying Fraction, (iv) Improper Fraction, and (v) Mixed Fraction. Figure 2 depicted the interface of the learning content that has been covered in the developed application. Basic zoom animation has been applied to introduce each of the subtopics to the intended users followed by an attractive voiceover by the character pronounced word by word clearly. Only one type of animation has been applied at this interface as the low vision children are unable to concentrate on various types of animation in one scene. This is to ensure they are able to grasp the main content displayed to them.

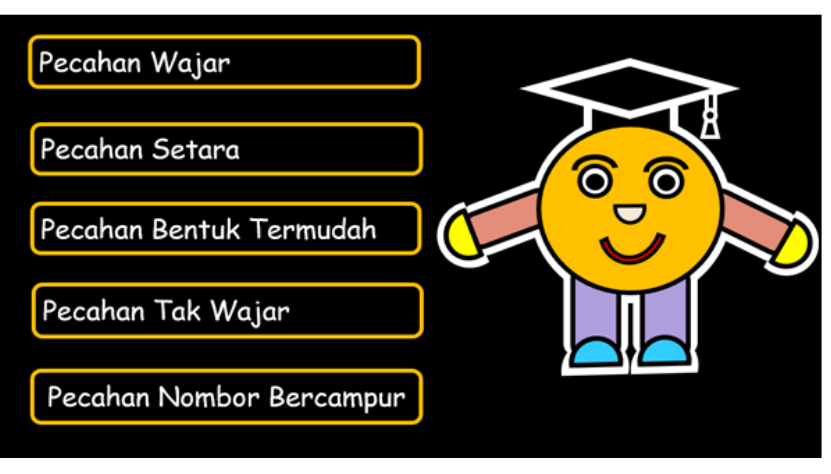

Figure 2. The interface design of the learning content

\subsection{The Script, Voice-over, and Intonation}

The script of Affective 4-Dimensional Mobile Mathematics for Low Vision Alpha Generation is related to the learning content. All objects and numeric values have been designed according to the suggestion of the experts. The script has been constructed scene by scene. Altogether there are 19 scenes to complete the subtopic of types of the fraction. Figure 3 displays the sample of the script for scene number four.

Perhatikan gambar rajah ini kawan-kawan
Sebuah segiempat sama dibahagikan kepada
empat bahagian... tiga bahagian diwarnakan..
Oleh itu, tiga daripada empat ialah tiga per
empat.
Tiga per empat ditulis 3/4.
Jadi $3 / 4$ ialah pecahan wajar. 3 dikenali sebagai
pengangka dan 4 dikenali sebagai penyebut.
Pecahan wajar bermaksud pengangka adalah
lebih kecil daripada penyebut.

Figure 3. The sample of the script

Meanwhile, for the voiceover, the woman's voice has been recorded. The woman's voice has been applied as it has been suggested by the experts that children prefer a woman's voice compared to a man's or machine voice. The innovation of the voiceover must be clear, and no complicated words have been utilized. All the words used in constructing the scripts have been checked and revised by the experts during the UCD process. Also, no background music is required as the low vision children need to give $100 \%$ concentration on the learning content. Furthermore, due to their limitation in eyesight, audio is the most important element in designing an application for low vision children. Therefore, the use of background music in designing and developing the Affective 4-Dimensional Mobile Mathematics for Low Vision Alpha Generation is meaningless. 


\subsection{The Character}

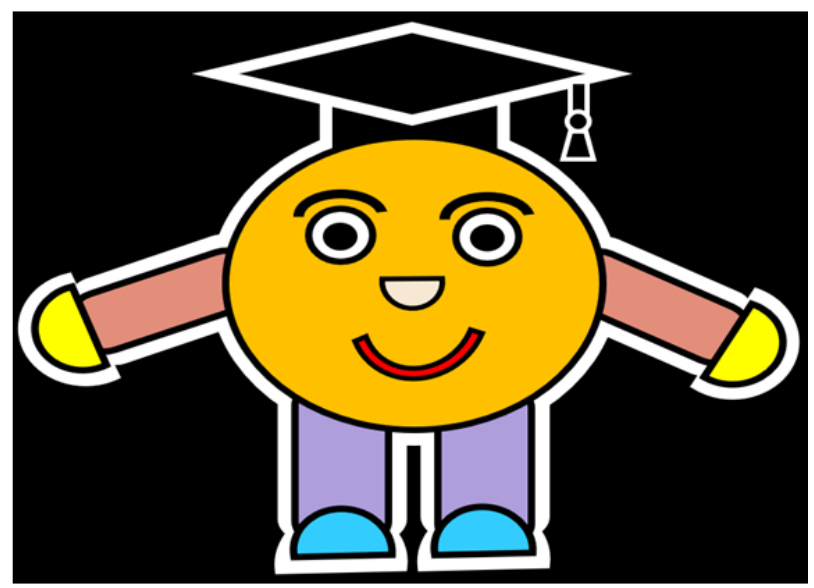

Figure 4. The character

The name of the character is Ecah. Ecah is the short form of the Malay word Pecahan. In English Pecahan is Fraction. As portrayed in Figure 4, the name of the character and the color played an important role in evoking the feelings and emotions of low vision children while they start the application. The character designed in Affective 4Dimensional Mobile Mathematics for Low Vision Alpha Generation must be in contrast with the background. The best contrast color that is appropriate to low vision children is the background is black and the character is a combination of light colors. Outline around the character with black and white is the best designed for low vision children. In this application, Ecah has been designed as the graduate figure to attract low vision children to trigger their positive interactions of learning experiences during the learning activities.

\subsection{The Objects}

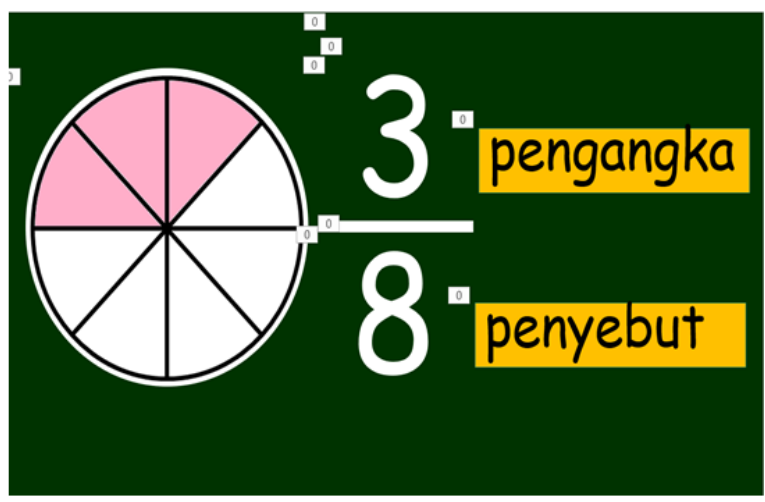

Figure 5. The sample of the object

The objects that have been designed for this application are suggested by the content experts. According to the content experts, geometry shapes are appropriate for low vision children to understand the concept of Fraction as they are at the beginner level. The types of geometry shapes that have been utilized are square, rectangle, circle, triangle, and pentagon. All of them are designed in contrast color to provide differences between the background and the object itself. Similar to the design of character, the objects also need to be outlined with the black and white color to attract the low vision children with the shape of the objects. As illustrated in Figure 5 the spatial between the object, the numerical value, and the words are important. As suggested by the experts, too much information in an interface is meaningless to low vision children. Therefore, provided the sequence transitions to appear each of the objects, numerical value, and words in a scene could provide the affective interactions to the intended users.

\subsection{The Numerical Values}

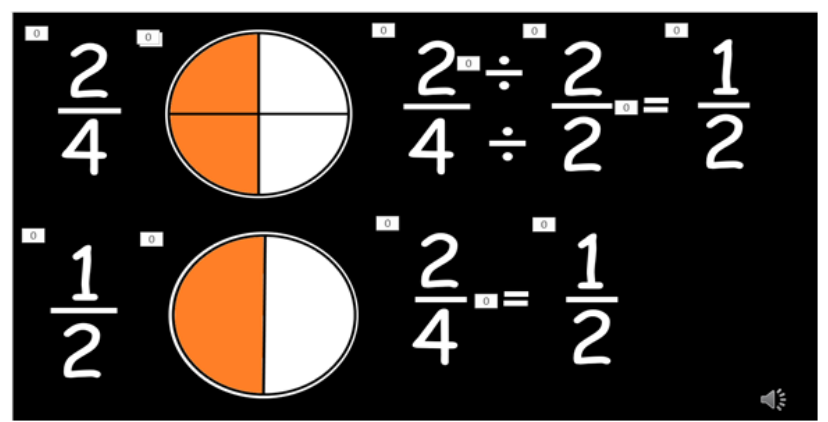

Figure 6. The sample of the numerical values

As depicted in Figure 6, the numerical values utilized in the developed application are small values. All the applied numerical values are as suggested by the content experts. It is appropriate to the intended users of the Affective 4-Dimensional Mobile Mathematics as they are at the beginner level. The most important is to ensure the developed application is able to provide the affective interactions to the low vision children during their learning activities.

\subsection{The Border}

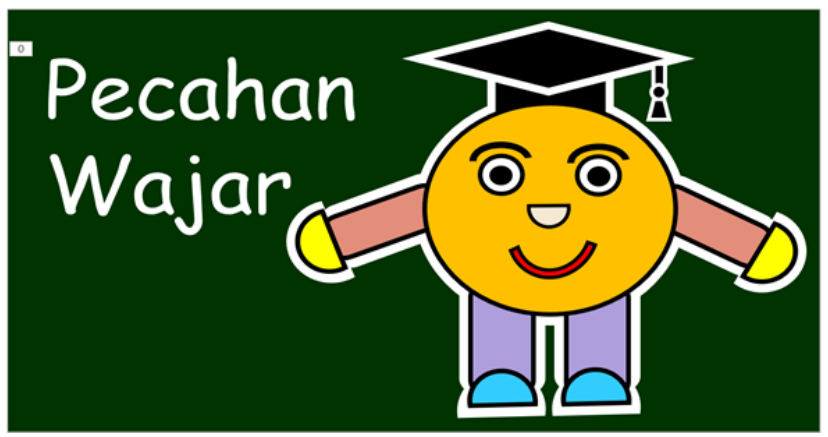

Figure 7. The sample of the border

Figure 7 illustrates the sample of the border between each of the subtopics. As recommended by the experts this application needs to have the border between each of the subtopics as all the contents are provided in linear style. There are no buttons, and no navigations are provided to the intended users. Therefore, the designed border could differentiate each of the subtopics. Only two types of information are designed for the border interface. As recommended by the content experts, it is sufficient for the border interface to have some texts that introduce the subtopics and the character to introduce the subtopic through the attractive voiceover. 


\subsection{The Mapping of Affective Design Component with the Proposed Application}

This section highlights the mapping of affective design components which are categorized into 4Dimension; (i) emotion, (ii) feeling, (iii) thought, (iv) action into Affective 4-Dimensional Mobile Mathematics for Low Vision Alpha Generation (Table 4).

Table 4. The mapping of affective components

\begin{tabular}{|c|c|c|}
\hline $\begin{array}{c}\text { Affective } \\
\text { Component }\end{array}$ & $\begin{array}{l}\text { Application } \\
\text { Component }\end{array}$ & Mapping Justification \\
\hline \multirow{3}{*}{ Emotion } & Script & $\begin{array}{l}\text { The word-by-word script } \\
\text { provided in the developed } \\
\text { application activates the } \\
\text { low vision children to be } \\
\text { happy as they use the } \\
\text { application. }\end{array}$ \\
\hline & Voice over & $\begin{array}{l}\text { The woman's voice-over } \\
\text { attracts the interest of low } \\
\text { vision children to continue } \\
\text { the learning activities until } \\
\text { the end of the syllabus. }\end{array}$ \\
\hline & $\begin{array}{c}\text { Voice } \\
\text { intonation }\end{array}$ & $\begin{array}{l}\text { The voice intonation } \\
\text { provides a surprise element } \\
\text { to low vision children } \\
\text { which then leads them to be } \\
\text { happy while enjoying the } \\
\text { learning activities. }\end{array}$ \\
\hline Thought & Objects & $\begin{array}{l}\text { The simple geometry shape } \\
\text { used to represent the } \\
\text { objects stimulates the } \\
\text { cognitive ability of low } \\
\text { vision children to grasp the } \\
\text { fraction concept. }\end{array}$ \\
\hline Feeling & Character & $\begin{array}{l}\text { The name of the character } \\
\text { "Ecah" triggers the users' } \\
\text { excitement and interest. } \\
\text { The figure of "Ecah" which } \\
\text { represents the graduate } \\
\text { character sparks the users to } \\
\text { feel inspired to learn } \\
\text { continuously. } \\
\text { The color combination is } \\
\text { not only accessible by low } \\
\text { vision children but also } \\
\text { attracts their attention. }\end{array}$ \\
\hline \multirow[b]{2}{*}{ Action } & $\begin{array}{l}\text { Border } \\
\text { Listed } \\
\text { menu }\end{array}$ & $\begin{array}{l}\text { The border and the listed } \\
\text { menu guide the low vision } \\
\text { children to navigate the } \\
\text { developed application. }\end{array}$ \\
\hline & $\begin{array}{l}\text { Numerical } \\
\text { value }\end{array}$ & $\begin{array}{l}\text { The selection of numerical } \\
\text { value provided in the } \\
\text { developed application } \\
\text { expresses the low vision } \\
\text { children interaction through } \\
\text { their reading action. }\end{array}$ \\
\hline
\end{tabular}

\section{Conclusion}

This study explores the affective domain components, which are emotion, feeling, thought, and action to suffice the learning needs for the low vision alpha generation. The inclusion of affective components and elements that have been extracted from previous study and UCD session were embedded in the mathematical application known as Affective 4-Dimensional Mobile Mathematics for Low Vision Alpha Generation. The 3-phase development model has been adapted to develop the application. Having satisfied the requirements of each phase, this study successfully delivered the learning content by utilizing the affective components and elements. Series of UCD sessions have been conducted to justify the design and development of Affective 4-Dimensional Mobile Mathematics for Low Vision Alpha Generation with the content experts. As suggested by [35] the inclusion of affective components enabled the users to internalize the learning content. Therefore, this study outlined and mapped the extracted components and elements of 4-dimensions of affective domains into the application. The next activity that will be conducted is a series of evaluations to validate the prototype through heuristic evaluation and user experience testing. In addition, with the advancement of educational technology, Affective 4-Dimensional Mobile Mathematics for Low Vision Alpha Generation will implement Augmented Reality as the future work to enhance its learnability and usability. It is targeted to integrate AR and emphasize on the 4dimension of affective components of the application. 


\section{Acknowledgment}

We thank the Universiti Teknologi MARA for granting this research under the Research Collaboration Fund (RCF). The research could be identified through the 600TNCPI 5/3/DDN (11) (003/2020). Our sincere gratitude also goes to all participants, experts, teachers, and students, who were involved in this study.

\section{References}

[1]. Kirboyun, S. (2020). High-Tech or Low-Tech? Impact of Assistive Technology in School Settings for Students with Visual Impairments: Review of Research. International Journal for Infonomics (IJI), 13(1).

[2]. Hamzah, A. A., Shaffiei, Z. A., Hamid, N. H. A., \& Aziz, N. (2021). MyAbility: A Web Portal for Students with Challenge based on Web Content Accessibility Guideline 2.0. Annals of Emerging Technologies in Computing (AETiC), 5(5).

[3]. Aziz, N., Mutalib, A. A., Ahmad, S. Z., Salam, S. N. A., \& Roseli, N. H. M. (2019, November). Initial Investigation on Affective 4D Mathematics Model for Low Vision Learners (AM4LV). In International Visual Informatics Conference (pp. 170-181). Springer, Cham.

[4]. Souza, A., \& Freitas, D. (2019, November). Technologies in Mathematics teaching: A transcript of the voices of visually impaired students, braille teachers, and screen readers. In 2019 International Symposium on Computers in Education (SIIE) (pp. 16). IEEE.

[5]. Spinczyk, D., Maćkowski, M., Kempa, W., \& Rojewska, K. (2019). Factors influencing the process of learning mathematics among visually impaired and blind people. Computers in biology and medicine, 104, 1-9.

[6]. Volta, E., Niewiadomski, R., Olugbade, T., Gilio, C., Cocchi, E., Berthouze, N., ... \& Volpe, G. (2019, September). Analysis of cognitive states during bodily exploration of mathematical concepts in visually impaired children. In 2019 8th International Conference on Affective Computing and Intelligent Interaction (ACII) (pp. 1-7). IEEE.

[7]. Rosenblum, L. P., Cheng, L., \& Beal, C. R. (2018). Teachers of students with visual impairments share experiences and advice for supporting students in understanding graphics. Journal of visual impairment \& blindness, 112(5), 475-487.

[8]. Jafri, R., Aljuhani, A. M., \& Ali, S. A. (2017). A tangible user interface-based application utilizing 3Dprinted manipulatives for teaching tactual shape perception and spatial awareness sub-concepts to visually impaired children. International Journal of Child-Computer Interaction, 11, 3-11.

[9]. Kocyigit, N., \& Artar, P. S. (2015). A challenge: Teaching English to visually-impaired learners. Procedia-Social and Behavioral Sciences, 199, 689-694.
[10]. Keeffe, J. (2019). Global data on vision loss: Implications for services. In The Routledge handbook of visual impairment (pp. 11-17). Routledge.

[11]. Senjam, S. S., Foster, A., \& Bascaran, C. (2021). Barriers to using assistive technology among students with visual disability in schools for the blind in Delhi, India. Disability and Rehabilitation: Assistive Technology, 16(7), 802-806.

[12]. Baharum, Z., Amran, A., Kamsul, B. A., Ahmad, N. A., \& Azmi, N. H. (2021, March). Data visualization for distribution of people with disabilities. In Journal of Physics: Conference Series (Vol. 1860, No. 1, p. 012001). IOP Publishing.

[13]. Mikulowski, D., \& Pilski, M. (2021, July). An approach for Describing unknown routes for the blind using three-dimensional binaural sound scenes in an ASR environment. In EdMedia+ Innovate Learning (pp. 378-385). Association for the Advancement of Computing in Education (AACE).

[14]. Dumkasem, K., Srisingchai, P., \& Rattanatamrong, P. (2019). EyeMath: Increasing Accessibility of Mathematics to Visually Impaired Readers. In 2019 23rd International Computer Science and Engineering Conference (ICSEC) (pp. 197-202). IEEE.

[15]. Beal, C. R., \& Rosenblum, L. P. (2018). Evaluation of the effectiveness of a tablet computer application (App) in helping students with visual impairments solve mathematics problems. Journal of visual impairment \& blindness, 112(1), 5-19.

[16]. Emerson, R. W., \& Anderson, D. (2018). What mathematical images are in a typical mathematics textbook? Implications for students with visual impairments. Journal of Visual Impairment \& Blindness, 112(1), 20-32.

[17]. Nguyen, A. M., Ferro, T. J., \& Pawluk, D. T. (2018). Effectiveness of Using Local Cues to Indicate Perspective in Tactile Diagrams for People with Visual Impairments. Journal of visual impairment \& blindness, 112(6), 731-744.

[18]. Hahn, M. E., Mueller, C. M., \& Gorlewicz, J. L. (2019). The Comprehension of STEM Graphics via a Multisensory Tablet Electronic Device by Students with Visual Impairments. Journal of Visual Impairment \& Blindness, 113(5), 404-418.

[19]. Calderon, C. A., Guajala, M., Lanchi, J., BarbaGuaman, L., Bermeo, C., \& Rivas-Echeverría, F. (2018, October). A machine vision system applied to the teaching of mathematics for blind or visually impaired children. In 2018 IEEE International Conference on Automation/XXIII Congress of the Chilean Association of Automatic Control (ICAACCA) (pp. 1-7). IEEE.

[20]. Li, Z., Tian, Z. G., Wang, J. W., Wang, W. M., \& Huang, G. Q. (2018). Dynamic mapping of design elements and affective responses: a machine learning based method for affective design. Journal of Engineering Design, 29(7), 358-380.

[21]. Bhandari, U., Neben, T., Chang, K., \& Chua, W. Y. (2017). Effects of interface design factors on affective responses and quality evaluations in mobile applications. Computers in Human Behavior, 72, 525534. 
[22]. Nalepa, G. J., Gizycka, B., Kutt, K., \& Argasinski, J. K. (2017). Affective Design Patterns in Computer Games. Scrollrunner Case Study. In FedCSIS (Communication Papers) (pp. 345-352).

[23]. Yusoff, Z., Kamsin, A., Shamshirband, S., \& Chronopoulos, A. T. (2018). A survey of educational games as interaction design tools for affective learning: Thematic analysis taxonomy. Education and Information Technologies, 23(1), 393-418.

[24]. Wang, C. H., \& Lin, H. C. K. (2018). Emotional design tutoring system based on multimodal affective computing techniques. International Journal of Distance Education Technologies (IJDET), 16(1), 103-117.

[25]. Benyon, D. (2019). Designing user experience. Pearson UK.

[26]. Berni, A., \& Borgianni, Y. (2021). From the Definition of User Experience to a Framework to Classify Its Applications in Design. Proceedings of the Design Society, 1, 1627-1636.

[27]. Özgür, A., \& Altun, A. (2021). Emotional Design and Engagement With Multimedia Learning Materials in E-Learning. In Motivation, Volition, and Engagement in Online Distance Learning (pp. 168191). IGI Global.

[28]. Hayes, L. J., \& Fryling, M. J. (2017). Feelings in psychological perspective. European Journal of Behavior Analysis, 18(1), 39-51.
[29]. Jeon, M. (2017). Emotions and affect in human factors and human-computer interaction: Taxonomy, theories, approaches, and methods. In Emotions and affect in human factors and human-computer interaction (pp. 3-26). Academic Press.

[30]. Yi, Q., Xiong, S., Wang, B., \& Yi, S. (2020). Identification of trusted interactive behavior based on mouse behavior considering web User's emotions. International Journal of Industrial Ergonomics, 76, 102903.

[31]. Alepis, E., Virvou, M., \& Kabassi, K. (2006, July). Affective student modeling based on microphone and keyboard user actions. In Sixth IEEE International Conference on Advanced Learning Technologies (ICALT'06) (pp. 139-141). IEEE.

[32]. Shamsuddin, N. A., Sulaiman, S., Syed-Mohamad, S. M., \& Zamli, K. Z. (2011, December). Improving learnability and understandability of a web application using an action-based technique. In 2011 Malaysian Conference in Software Engineering (pp. 245-250). IEEE.

[33]. Darsareh, J., \& Nikafrooz, M. (2021). An Introduction to E-Content Producing Algorithm for Screen-Recorded Videos. In Conference Proceedings, Zurich Switzerland September (Vol. 16, p. 17).

[34]. Harmayani, H., Apdilah, D., Helmiah, F., Siagian, Y., \& Syah, A. Z. (2021). Interaksi Manusia dan Komputer. Yayasan Kita Menulis.

[35]. Kitkowska, A., Shulman, Y., Martucci, L. A., \& Wästlund, E. (2020, September). Facilitating Privacy Attitudes and Behaviors with Affective Visual Design. In IFIP International Conference on ICT Systems Security and Privacy Protection (pp. 109123). Springer, Cham. 